\title{
Povijesni pregled razvoja riječke tvornice papira
}

\section{Historical Overview of the Development of the Rijeka Paper-mill}

\author{
Stručni rad • Professional paper \\ Prispjelo-received: 25. 10. 2010. \\ Prihvaćeno-accepted: 27. 4. 2011. \\ UDK: $630 * 861$ \\ doi:10.5552/drind.2011.1035
}

\begin{abstract}
SAŽETAK • Povijest jedne od prvih i najutjecajnijih tvornica papira u Hrvatskoj počinje industrijski davne 1821. godine u Rijeci. Uz odvažne investicije i pogonske modernizacije tvornica je rasla i stjecala ugled na europskoj i svjetskoj razini. Zasluge za impozantne poslovne rezultate treba pripisati vizionarima, počevši od prvog vlasnika Andrije Ljudevite Adamicha, preko idućih vlasnika i upravitelja Charlesa te, kasnije Henryja Meyniera, te, poglavito, Eugenea Frémonta. Razvoj tvornice odražavao se i na razvoj gradova Sušaka i Rijeke, poglavito u smislu elektrifikacije, ali $i$ životnog standarda građana. U najplodnijim razdobljima u tvornici je radilo više od 1 000 radnika, a godišnji volumen proizvodnje premašivao je 8000 tona. Više puta tijekom 180-godišnjega radnog vijeka tvornica je doživjela havarije, od poplava do požara, no posljednji gospodarski udar 2005. godine nije uspjela preživjeti.
\end{abstract}

Ključne riječi: Riječka tvornica papira, povijesni pregled, industrijska proizvodnja papira, inovacije i kapaciteti, svjetski ugled

\begin{abstract}
The history of one of the first and most important paper-mills in Croatia begins in the industrially distant year of 1821 in Rijeka. Thanks to courageous investments and propelling power modernizations, the factory grew and gained reputation on the European and world scene. The credit for impressive business results goes to the visionaries starting with the first owner Andrija Ljudevit Adamich, subsequent owners and managers Charles and (later also) Henry Meynier, and especially Eugene Frémont. The development of the factory affected the development of the cities of Sušak and Rijeka, especially in terms of electrification, but also the living standard of the citizens. At the peak of its production more than a thousand workers were employed in the factory, and the yearly output exceeded 8000 tonnes. The paper-mill experienced severe damages several times during its 180 years of working life, both floods and fire, but the fatal shock that the factory could not survive was the economic one in 2005.
\end{abstract}

Key words: the Rijeka paper-mill, historical overview, industrial paper production, innovations and capacities, world reputation

\section{UVOD}

\section{INTRODUCTION}

Povijest jedne od prvih i najutjecajnijih industrija papira u Hrvatskoj počinje davne 1821. godine u Rijeci, administrativnom središtu Primorsko-goranske županije i najvažnijoj hrvatskoj luci. Taj se treći po veličini grad u Hrvatskoj zbog svoga idealnog zemljopisnog položaja i pristupa sjevernom Jadranu i Kvarnerskom zaljevu razvio u jednu od najvećih srednjoeuropskih luka i jako industrijsko središte. Rijeka je bila poznata i kao jedno od najvažnijih financijskih središta tijekom svoje povijesti i upravo zbog brojnih prednosti koje je nudila bila je pravi izbor za otvaranje tvornice papira (sl. 1).

\footnotetext{
${ }^{1}$ Autorice su magistrica grafičke tehnologije i izvanredna profesorica Grafičkog fakulteta Sveučilišta u Zagrebu, Zagreb, Hrvatska.

${ }^{1}$ The authors are a master of science of graphic technology and an associate professor at the Faculty of Graphic Arts of the University of Zagreb, Croatia.
} 


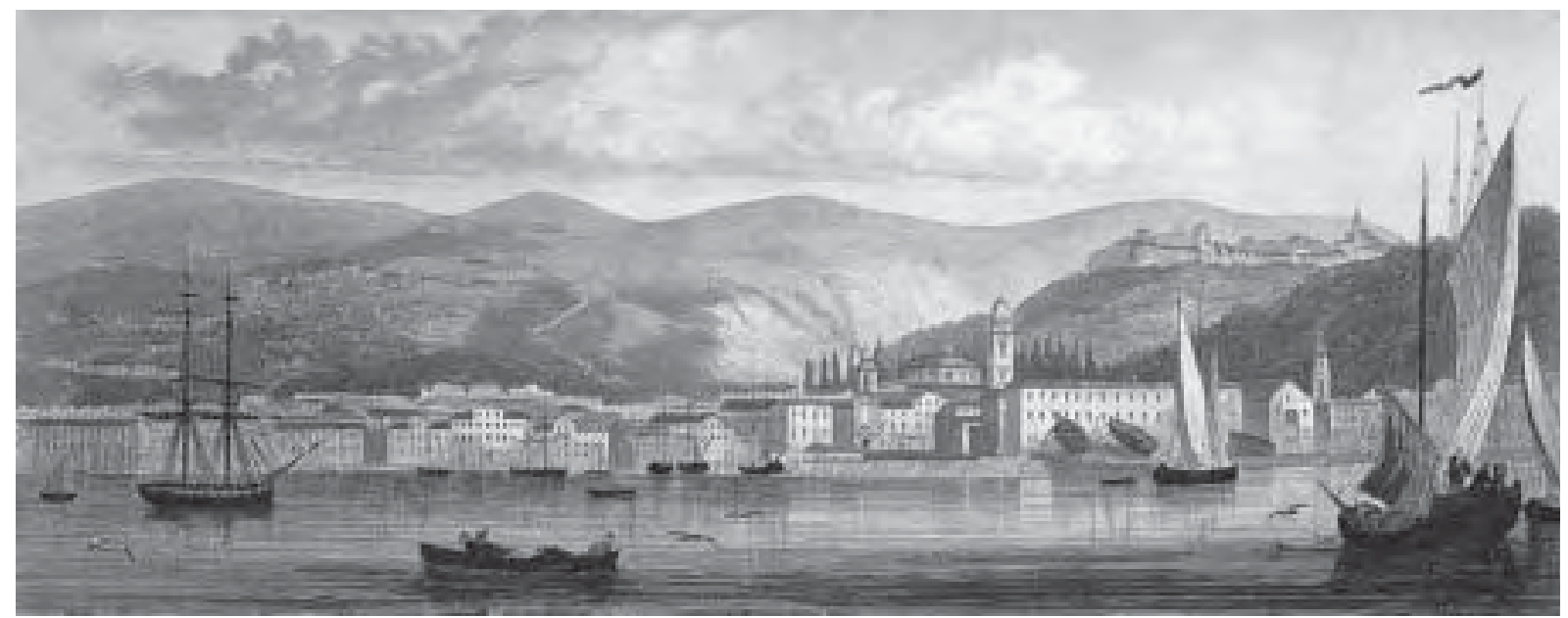

Slika 1. Grad Rijeka, 1850. g. (http://muzej-rijeka.hr, 2010)

Figure 1 The city of Rijeka, 1850 (http://muzej-rijeka.hr, 2010)

\section{OSNUTAK TVORNICE PAPIRA RIJEKA} 2 FOUNDING OF THE RIJEKA PAPER-MILL

Prvi koraci u pokretanju proizvodnje papira zbivali su se u doba teških političkih, gospodarskih i socijalnih kriza u Europi koje su grad dovele do potpunoga gospodarskog osiromašenja. U svim tim teškim okolnostima našao se čovjek koji je imao dovoljno hrabrosti pokrenuti i iz siromaštva stvoriti tvornicu koja se uspjela uzdići i zadržati tijekom dugih 180 godina neprekidne proizvodnje. Taj veliki korak učinio je Andrija Ljudevit Adamich, jedan od najistaknutijih i najsvestranijih riječkih poduzetnika čija je mreža poslovanja sezala i do prekooceanskih zemalja (Afrike, Kube,

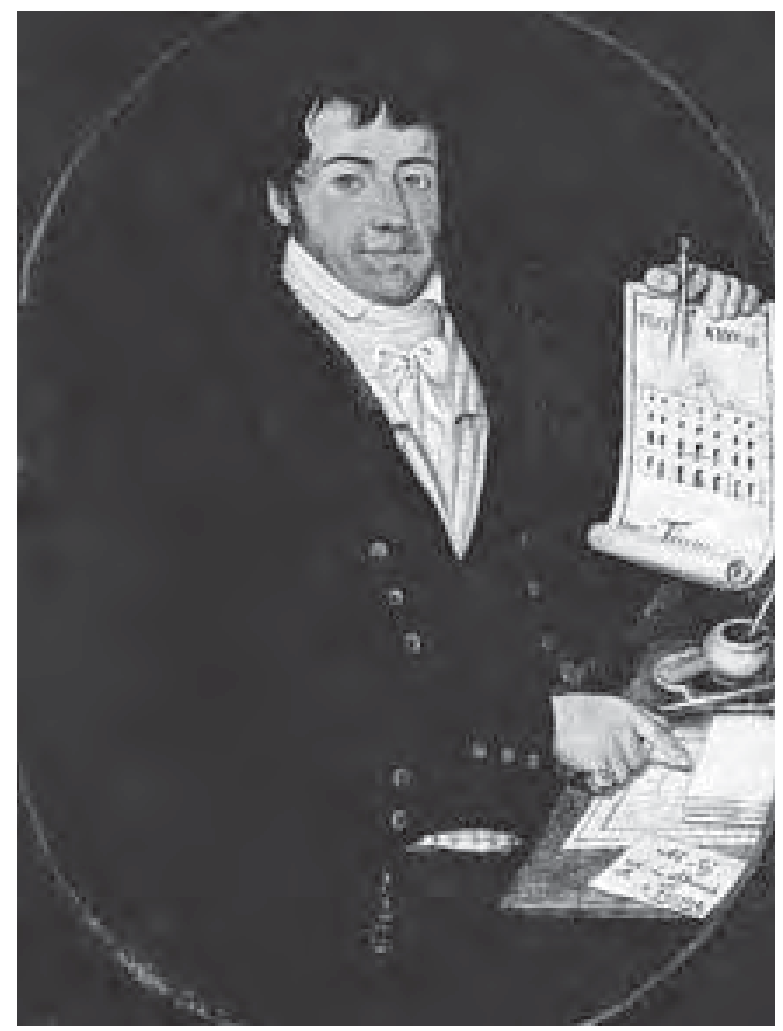

Slika 2. Andrija Ljudevit Adamich (http://muzej-rijeka.hr, 2010)

Figure 2 Andrija Ljudevit Adamich (http://muzej-rijeka.hr, 2010)
Brazila itd.). Kao početak - datum rođenja tvornice u Rijeci - zapisan je rujan 1821. (Lisac, 1961). Te je godine A. Lj. Adamich kupio mlin na Lučicama, u dolini Rječine, i preuredio ga za proizvodnju papira (sl. 2), te zaposlio 21 radnika.

Godine 1824. A. Lj. Adamich je zbog velike zauzetosti i drugih poslovnih prilika koje su mu se otvarale prodao mlin engleskom industrijalcu Williamu Molineu, izdanku ugledne obrtničke obitelji. No nakon samo tri godine Moline je prodao tvornicu engleskim industrijalcima Charlesu Meynieru (sl. 3) i Walteru Craftonu Smithu za 14000 zlatnih franaka (Lisac, 1961). Novi su vlasnici od samog početka u tvornicu ulagali znatan kapital osiguravajući tako njezin razvoj i modernizaciju. Sva ta ulaganja i rad ostvaren u tvornici nisu ostali bez rezultata. U Rijeci se proizvodio papir koji je svojom kvalitetom odnosio pobjede na najvećim smotrama tog vremena u svijetu. Riječki se papir prodavao na svim kontinentima, u ukupno pedeset zemalja svijeta.

Prvi tehnološki ulog u tvornicu bio je Fourdrinierov stroj za izradu papira, tzv. papir-stroj, najmoderniji u tadašnjoj austrijskoj carevini, na kojemu se proizvodila kontinuirana traka papira, $u$ to vrijeme vrhunac tehnoloških dostignuća u industriji papira. Danas se pod tim nazivom misli na dio papir-stroja s ravnim dugim sitima na kojima se odvaja najveći dio vode od celuloznih vlakana.

Pogonsku snagu tog stroja činili su vodeni kotači, a potrebna se voda dovodila s obale Rječine uz pomoć drvenih vodova. Taj je sustav omogućivao stvaranje energije od 300 konjskih snaga. $U$ to vrijeme tvornica je zapošljavala oko 250 radnika. Njezini su proizvodi ponajprije bili namijenjeni izvozu, dok su se na domaćem tržištu pojavili tek 1878. g. (Lisac, 1961).

Zbog velikog broja narudžbi i potrebe za što većom energijom, u tvornici je 1833. g. instaliran parni stroj, prvi na jugoistoku Europe, a nedugo nakon toga instaliran je i drugi Fourdrinierov papir-stroj. Prvu službenu potvrdu kvalitete svojih proizvoda tvornica je dobila na Prvoj industrijskoj izložbi održanoj u Beču 1835. g. dobivši srebrnu medalju, prvo u nizu priznanja koja su slijedila (sl. 3). 


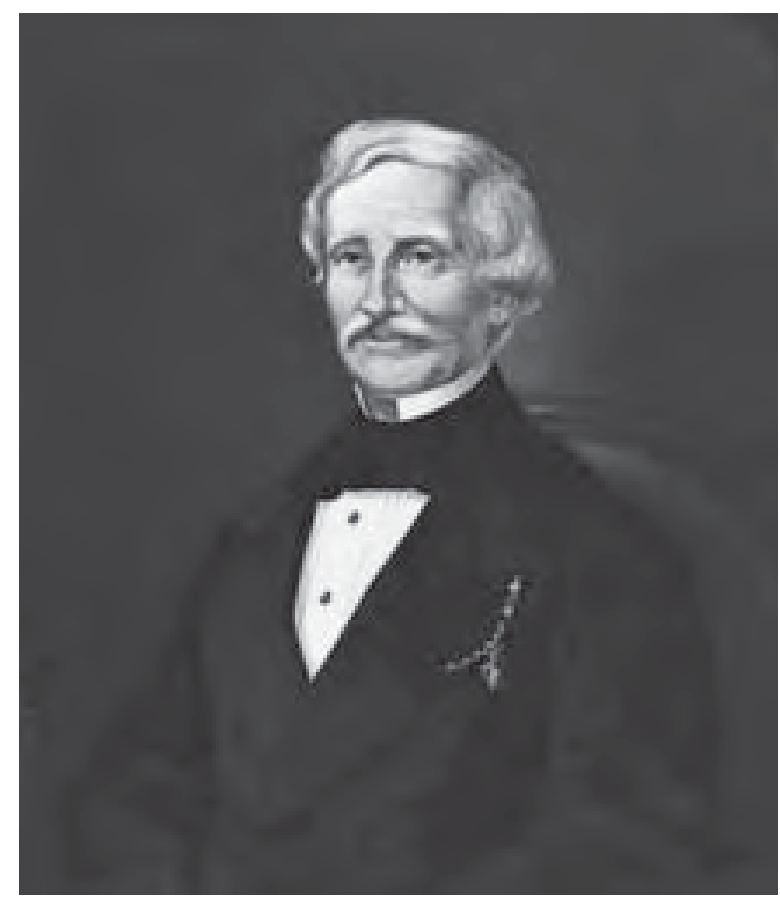

Slika 3. Charles Meynier (http://muzej-rijeka.hr, 2010) Figure 3 Charles Meynier (http://muzej-rijeka.hr, 2010)

\section{USPON TVORNICE PAPIRA RIJEKA} 3 THE RISE OF THE RIJEKA PAPER-MILL

U uzlaznoj putanji razvoja tvornici se 1838. g. pridružio Eugene Frémont, stručnjak, organizator i predani tehnički inovator iz Dreuxa u Francuskoj. Svoje znanje i sposobnosti pokazao je na mjestu tehničkog ravnatelja i ponajprije njemu pripada zasluga za tehnički napredak tvornice, na čijem je vrhu kao ravnatelj proveo punih četrdeset i osam godina (http://muzej-rijeka.hr, 2010). Usporedno s poslovanjem u Rijeci, putovao je u Francusku, gdje je znao provesti i godinu dana kako bi u tamošnjim tvornicama papira proučio najnovija tehnička dostignuća na području proizvodnje papira te ih primijenio u riječkoj tvornici. Godine 1841. tvornici se pridružila još jedna osoba, koja će dugo sudjelovati u njezinu razvoju i ostaviti svoj trag. Bio je to Henry Meynier, nećak Charlesa Meyniera, koji će neprekidno djelovati u tvornici čak 70 godina (sl. 4). Tijekom njegova upravljanja tvornica je doživjela brojne uspone, ali i padove. Prvi takav pad dogodio se 11. listopada 1852, kada je velika poplava, nastala izlijevanjem Rječine iz korita, u potpunosti uništila tvornicu. Skladišta su bila poplavljena, a strojevi teško oštećeni. Taj udarac ipak nije doveo do zatvaranja tvornice, već je, naprotiv, tvornica potpuno preuređena i modernizirana (Lisac, 1961).

Krajnji rezultat te obnove bila je potpuno nova tvornica, znatno većeg kapaciteta od prethodne. Glavni voditelj obnove bio je Frémont. Stari vodeni kotači zamijenjeni su turbinama, pritok vode urađen je prema novim i tehnološki modernijim nacrtima, a drvenu branu zamijenila je betonska. Zbog potrebe dovoda vode prokopano je brdo uz obalu Rječine, pa se voda na turbine dovodila kroz tunel. Bili su potrebni i novi parni uređaji, čime se ukupna pogonska snaga tvornice s pri-

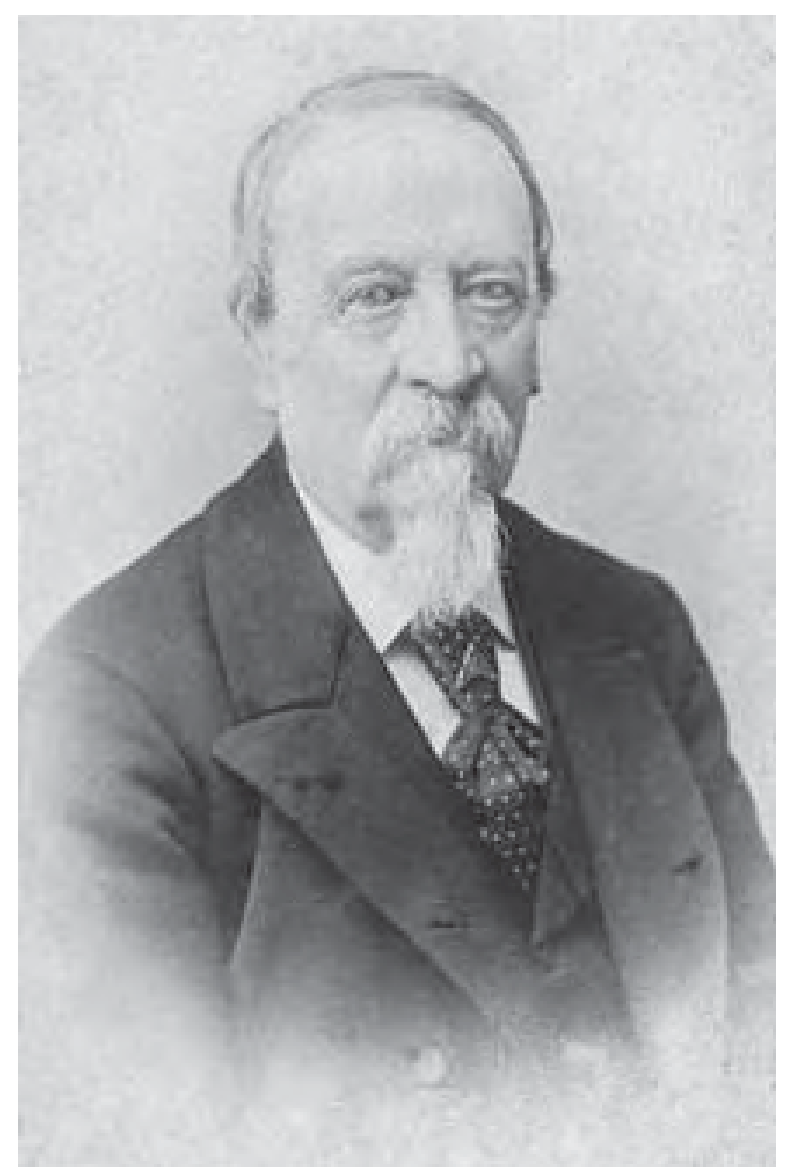

Slika 4. Henry Meynier (http://muzej-rijeka.hr, 2010)

Figure 4 Henry Meynier (http://muzej-rijeka.hr, 2010)

jašnjih 300 povećala na 600 konjskih snaga. U to vrijeme pogoni tvornice zapošljavali su nevjerojatnih 600 radnika. Zahvaljujući pozitivnom poslovanju, tvornica je othranjivala generacije radnika s područja Grobnika i Trsata - u njoj bi radili otac, sin, unuk - i tako iz generacije u generaciju (http://muzej-rijeka.hr, 2010). Potrebe proizvodnje zahtijevale su nabavu još dva papir-stroja. Veliko gospodarsko značenje tvornice za tadašnju Hrvatsku naglašavali su i predstavnici hrvatskoga narodnog preporoda i grof Janko Drašković (Lisac, 1961), koji je kasnije inicirao osnivanje zagrebačke tvornice papira (Lozo, 2001).

Novi val unapređenja tvornice zabilježen je 1872. godine, još uvijek pod uspješnom upravom Eugenea Frémonta. Tada je izgrađena nova brana, a istodobno je izgradnjom novog tunela pogonska vodena snaga dosegla jačinu od 1200 konjskih snaga. Te iste godine osnovana su zastupništva sa skladištima svih vrsta papira u Beču i Budimpešti. Na taj način tvornica je mogla uspješno sudjelovati na javnim licitacijama za dobavu papira za državnu tiskaru (sl. 5). Godine 1867. tvornica je dobila još jedno tehničko pojačanje - automatizirani stroj za proizvodnju papira, koji je u tvornicu dopremljen odmah nakon prezentacije na pariškoj izložbi.

Riječka tvornica papira bila je poznata i po proizvodnji cigaretnog papira, koji se prvi put počeo proizvoditi 1890. g. Po proizvodnji cigaretnog papira bila je na drugome mjestu u Europi. Te godine tvornica je zapošljavala 629 radnika, koji su radili na pet strojeva 


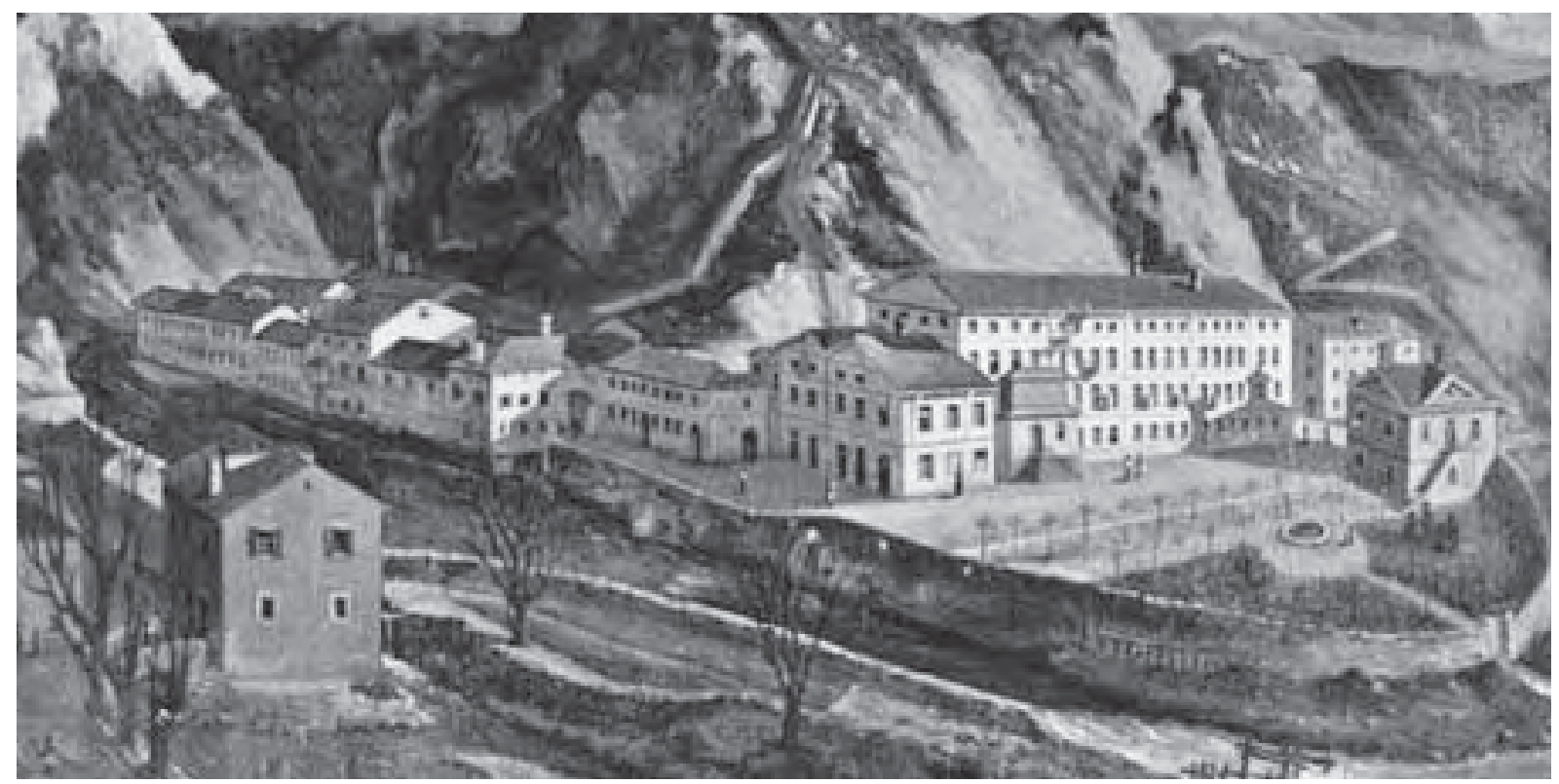

Slika 5. Tvornica papira Rijeka, 1860. g. (www.klub-susacana.hr, 2010)

Figure 5 The Rijeka Paper-mill, 1860 (www.klub-susacana.hr, 2010)

za proizvodnju papira. Godine 1896. tvornica je proizvodila ukupno oko 24000 kvintala papira, što znači oko 2400 tona, od čega za pisanje i crtanje 15000 , omotnog 5 000, tiskovnog 2000 i cigaretnog papira 2000 kvintala (Lisac, 1961).

\section{GOSPODARSKA KRIZA I PAD TVORNICE 4. ECONOMIC CRISIS AND DECLINE OF THE FACTORY}

Krajem osamdesetih godina 19. st. za riječku tvornicu papira počinje razdoblje pada i stagnacije. Tu je krizu uzrokovala zamjena sirovina za proizvodnju papira - umjesto krpa, tj. tekstilnih otpadaka kao sirovine, kojih je bilo razmjerno sve manje, tražio se izlaz u sirovini bogatoj vlaknima, i to onoj koje ima dovoljno u prirodi. Stoga su se počela upotrebljavati drvna celulozna vlakna (Golubović, 1984). Problem je bio u tome što se veće količine te sirovine nisu mogle nabavljati na domaćem tržištu po povoljnim uvjetima, pa je uvoz drva i prerađene celuloze bio velik trošak. Visoke cijene sirovina uvjetovale su znatno povećanje troškova proizvodnje, što je utjecalo na smanjenje profita.

Od 1887. do 1911. g. tvornica je bilježila više teških trenutaka. Pogone su zahvatila čak četiri požara, nakon kojih su slijedili skupi popravci i ulaganja u obnovu. Prvi požar izbio je 1887. g., i u njemu je izgorio dio tvornice zvan „Marganovo”. Drugi je požar izbio 1903. g. i uništio zgradu koja je pripadala starom dijelu tvornice. Treći je požar zahvatio odjel za krpe 1904. g. i potpuno ga uništio, a ista je sudbina taj odjel pogodila i 1911. g. Osim požara, tvornicu je 8. listopada 1898. g. pogodila i druga poplava napravivši veliku štetu i uništivši u cijelosti elektranu i nekoliko novih strojeva koji su u pogon pušteni samo nekoliko dana prije toga (http://muzej-rijeka.hr, 2010).

Pokazatelj krize je podatak da su tijekom 1901. g. u pogonu radila samo tri papir-stroja, a smanjen je i broj zaposlenih, najprije na 450 radnika, a već sljedeće

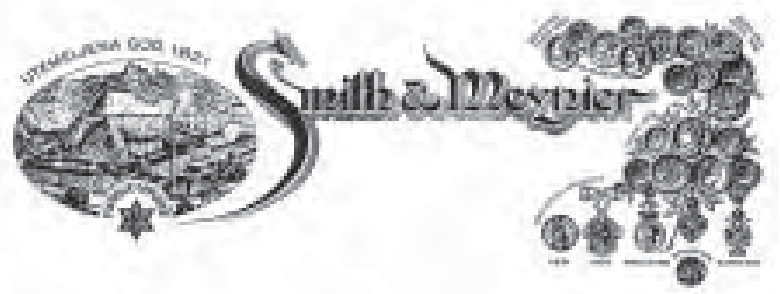

Slika 6. Natpis i logo tvornice (http://muzej-rijeka.hr, 2010) Figure 6 The factory lettering and logo (http://muzej-rijeka.hr, 2010)

godine na samo 290. Sredinom lipnja 1903. g. vlasnik trgovačke tvrtke Smith \& Meynier Henry Meynier zbog nemogućnosti osiguranja prijeko potrebnih financijskih sredstava pretvorio je tvornicu u obiteljsko dioničko društvo pod nazivom Smith \& Meynier - prva kraljevska povlaštena riječka tvornica papira (sl. 6).

Do 1906. g. jedini vlasnik poduzeća bila je obitelj Meynier, ali nakon toga u poslovanje se sve više uključivala Prva ugarska industrija papira d.d. Svoj utjecaj novi su dioničari pokazali odlukom da se od 1910. g. proizvodnja usmjeri isključivo na proizvodnju cigaretnog papira. Nakon te odluke iz poduzeća su uklonjeni svi strojevi koji su bili namijenjeni proizvodnji ostalih vrsta papira, iako je potražnja za njima i dalje postojala (Lozo, 2007).

\section{RIJEČKA TVORNICA PAPIRA TIJEKOM 20. STOLJECA \\ 5 THE RIJEKA PAPER-MILL DURING THE $20^{\text {TH }}$ CENTURY}

Raspadom Austro-Ugarske Monarhije prestaje utjecaj mađarskog kapitala koji je dotad bio zastupljen u upravi tvornice. Godine 1922. sjedište tvornice premješteno je iz Rijeke u Zagreb jer se tvornica udružila s kompanijom „Jela - industrija papira”, no 1925. g. to je partnerstvo raskinuto i tvornica je pala pod upravu 
Prve hrvatske štedionice. Zbog potrebe veće učinkovitosti u vođenju tvornice, 1926. g. osnovan je Mjesni odbor ravnateljskog vijeća Smith i Meynier tvornice papira na Sušaku (Lozo, 2001). Na čelu tog odbora bio je Milivoj Crnadak.

U tom razdoblju kompleks tvornice činila su četiri glavna dijela:

1. odjel za krpe i sirovine (sl. 7),

2. stara tvornica - u kojoj se ponovno proizvodio pisaći i tiskovni papir,

3. nova tvornica - u kojoj se proizvodio svileni i cigaretni papir (sl. 8),

4. Marganovo - gdje se proizvodio papir za pakiranje.

Cijeli kompleks sastojao se od 66 građevina koje su se prostirale na površini većoj od $72000 \mathrm{~m}^{2}$. Na tri papir-stroja tvornica je proizvodila više vrsta papira: cigaretni papir, svileni papir, papir za kopiranje, biblijski i oslojeni (premazani) papir itd. a godišnja proizvodnja iznosila je 1200 tona.

Proizvodi su se izvozili po cijelom svijetu, no u uvozu riječkih papira prednjačili su SAD, Argentina, Španjolska, Rumunjska, Egipat i zemlje Dalekog istoka. Prepoznatljivi simbol tvornice, koji postoji i danas, bio je 83 metara visok dimnjak sagrađen uz električnu centralu. Ta je centrala osim tvornice dugi niz godina $u$ razdoblju prije Drugoga svjetskog rata električnom energijom opskrbljivala i grad Sušak.

Još 1910. g. uprava tvornice uvidjela je prednosti proizvodnje cigaretnog papira i preorijentirala se pretežito na njegovu proizvodnju, te do 1939. g. $70 \%$ ukupne proizvodnje otpada na taj papir. Ta preorijentacija u proizvodnji dovela je do učlanjenja tvornice u Sindikat tvorničara cigaretnog papira u Parizu. Oko 1940. g. tvornica je ponovno radila svojim punim kapacitetom i

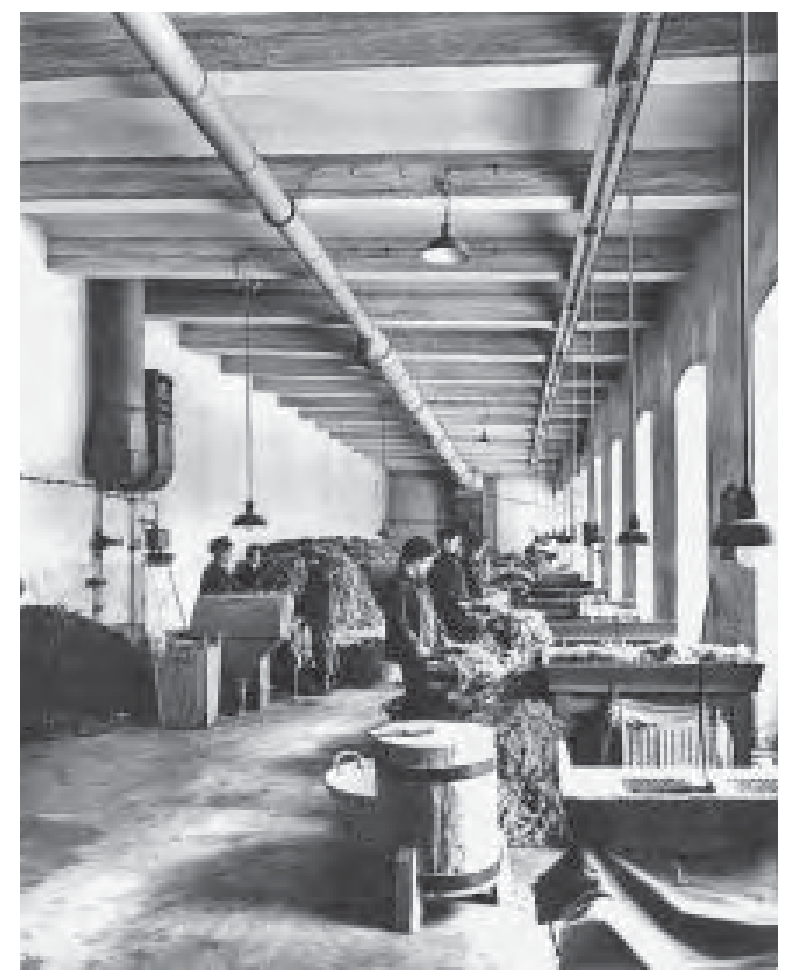

Slika 7. Krparnica (http://muzej-rijeka.hr, 2010)

Figure 7 Rags as raw material (http://muzej-rijeka.hr, 2010)

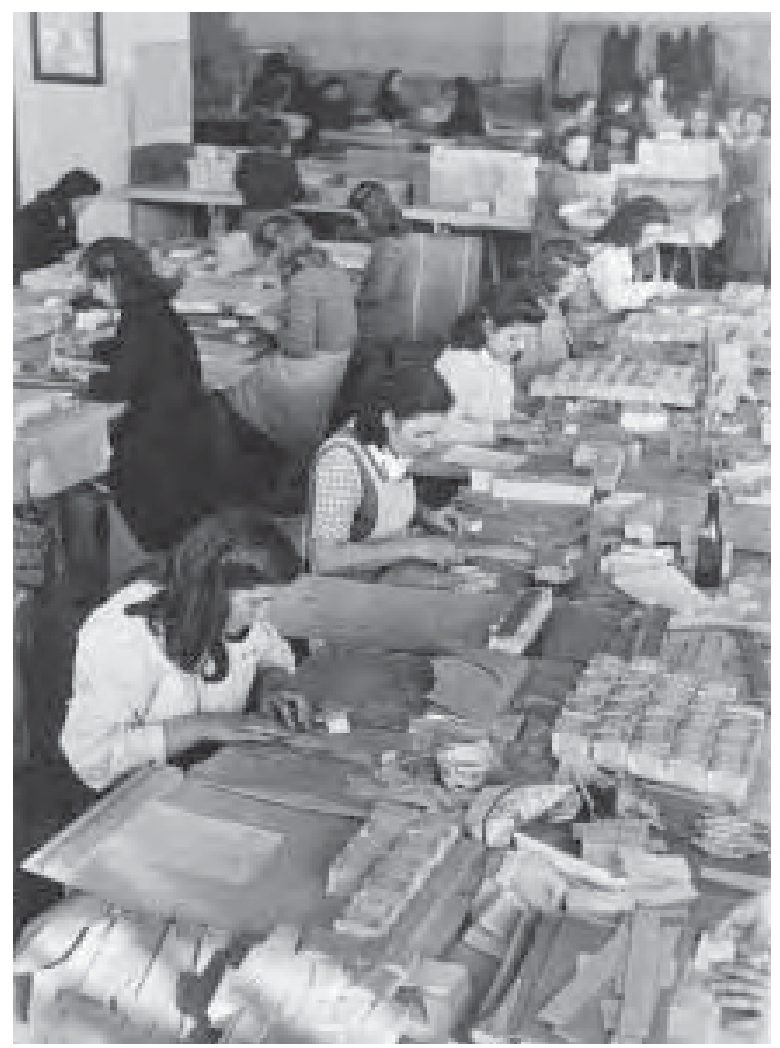

Slika 8. Odjel cigaretnog papira (http://muzej-rijeka.hr, 2010)

Figure 8 Department of cigarette paper (http://muzej-rijeka.hr, 2010)

raspolagala najsuvremenijim postrojenjem za proizvodnju papira, a zapošljavala je 497 radnika (sl. 9). U najkritičnijim trenucima prije kraja Drugoga svjetskog rata, zahvaljujući organizaciji radnika, tvornička su postrojenja u cijelosti sačuvana od razaranja i uništenja.

Nakon oslobođenja Sušaka od talijanske okupacije 1. svibnja 1945. tvornicu je preuzela ,narodna vlast" te je prešla u državno vlasništvo. U to vrijeme tvornica je ponovno proizvodila sve vrste papira, a kvaliteta papira i opseg proizvodnje kontinuirano su rasli, a s njima i broj radnika. Tako su 1950. proizvodnju od 3500 tona papira godišnje ostvarivala 634 radnika. Povijesna je zanimljivost da je tvornica osnivanjem Radničkog savjeta među prvima, 31. siječnja

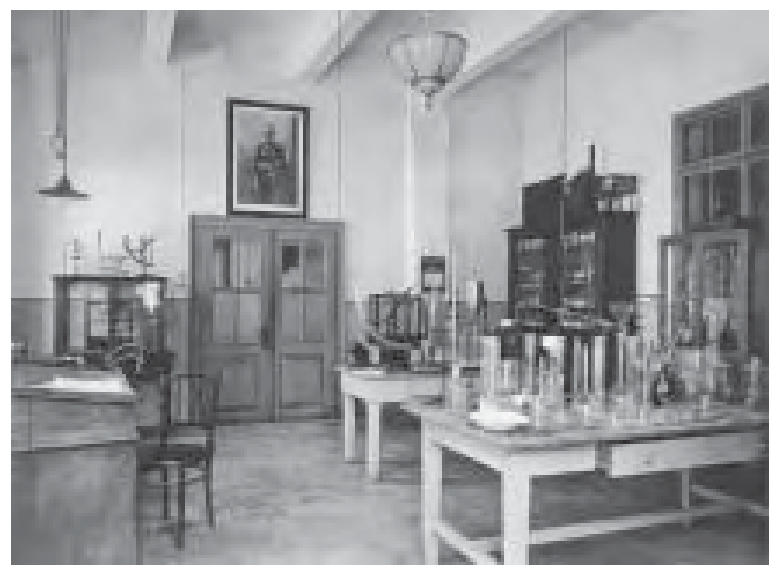

Slika 9. Kemijski laboratorij (http://muzej-rijeka.hr, 2010) Figure 9 Chemical laboratory (http://muzej-rijeka.hr, 2010) 
1950, u tadašnjoj FNRJ uvela model radničkog samoupravljanja.

Godine 1962. tvornica je ponovno modernizirana i proizvodnja papira povećala se na 8000 tona u godini. U sklopu tvornice osnovana je jedina tvornica parafinskih šibica u zemlji, čija je proizvodnja iznosila i do 55 milijuna kutija u godini. Svoju uzlaznu putanju tvornica je zadržala sve do 1991. g., kada je bila na drugome mjestu u Europi po količini proizvedenog cigaretnog papira, a u svjetskim razmjerima držala je čak $5 \%$ ukupne količine proizvedenog papira te vrste (http://muzej-rijeka.hr, 2010).

$\mathrm{Na}$ tom vrhuncu uspješnosti u tvornici je radilo čak 1150 radnika, a $80 \%$ ukupnih proizvoda izvozio se (http://muzej-rijeka.hr, 2010).

Promjene u organizaciji vlasničkih udjela, kao i u tržišnom natjecanju 1990-ih godina, odrazile su se na proizvodnju i poslovanje tvornice. Osim toga, ratna događanja koja su zahvatila osamostaljenu Hrvatsku dodatno su otežala poslovanje, zastoji u tehničkom transportu sirovina remetili su kontinuiranu proizvodnju ali i isporuku, naručitelji su se počeli osipati i promet se dramatičnom brzinom smanjivao. Nakon teških ratnih i poratnih vremena tvornica papira izgubila je gotovo sve svoje nekadašnje tržište, što je konačno rezultiralo proglašenjem stečaja 2005. g. i zatvaranjem te slavne tvornice. No objekti tvornice nisu potpuno pali u zaborav. Objekt Marganovo preuzeo je grad Rijeka i pod današnjim nazivom Hartera preuređen je kao rekreacijski prostor za mlade.

\section{LITERATURA}

\section{REFERENCES}

1. Golubović, A., 1984: Tehnologija izrade i svojstva papira, Zagreb, Viša grafička škola.

2. Lisac, A. Lj., 1961: Razvoj industrije papira u Zagrebu, Zagreb, Zagrebačka tvornica papira.

3. Lozo, B., 2007: Povijesni pregled izrade papira, Theaurus Archigymnasii, Zagreb, Klasična gimnazija.

4. Lozo, B.; Vujnović, M.; Bertić, I., 2001: Proizvodnja papira - crtice iz prošlosti, Zbornik radova "Blaž Baromić", Senj, Matica hrvatska - Ogranak Senj.

5. *** http://muzej-rijeka.hr/projekti.asp

6. $* * *$ http://muzej-rijeka.hr/tvornica-papira/index.html

7. $* * *$ http://www.klub-susacana.hr/revija/clanak.asp?Num $=42-43 \& \mathrm{C}=20$

\section{Corresponding address:}

Assoc. Prof. BRANKA LOZO, Ph.D.

Grafički fakultet

Sveučilište u Zagrebu

Getaldićeva 2

HR-10000 Zagreb, CROATIA

E-mail: branka.lozo@grf.hr

Napomena:

Rad je dijelom objavljen u diplomskom radu Maje Hadžić 2010. g. pod nazivom Povijesni pregled razvoja papirne industrije u Hrvatskoj, http://bib.irb.hr/ prikazi-rad? \& $\mathrm{rad}=479396$ 